\title{
Effects of Rape Rootstock on Nutrient Uptake and Soil Enzyme Activity of Post-Grafting Generation of Capsella bursa-pastoris under Cd Stress
}

\author{
Jin Wang ${ }^{1, a}$, Jun Shi ${ }^{2, b}$, Shuting Yang ${ }^{1, \mathrm{c}}$ and Xiulan $L v^{3, \mathrm{~d} *}$ \\ ${ }^{1}$ College of Horticulture, Sichuan Agricultural University, Chengdu, Sichuan, China \\ ${ }^{2}$ Mianyang Academy of Agricultural Sciences, Mianyang, Sichuan, China \\ ${ }^{3}$ Institute of Pomology and Olericulture, Sichuan Agricultural University, Chengdu, Sichuan, China

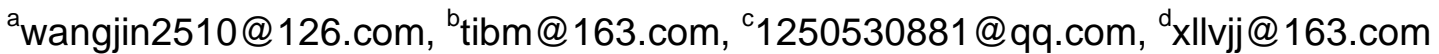 \\ ${ }^{*}$ Corresponding author
}

Keywords: Rape rootstock; Post-grafting generation; Capsella bursa-pastoris; Nutrient; Soil enzyme activity

Abstract. The effects of rape rootstock on phosphorus (P) and potassium (K) uptake and soil enzyme activity of post-grafting generation of Capsella bursa-pastoris under cadmium (Cd) stress was investigated through two pot experiments. Three treatments were used in the experiment: ungrafted (UG), post generation of self-rooted grafting by the two C. bursa-pastoris seedling (PSG) and post generation of grafting on the rootstock of rape (PRG). In high and low soil $\mathrm{Cd}$ concentration experiments, the grafting increased $\mathrm{P}$ and $\mathrm{K}$ contents in roots and shoots of post-grafting generation plants of $C$. bursa-pastoris compared with UG under $\mathrm{Cd}$ stress. The $\mathrm{P}$ and $\mathrm{K}$ contents in plants were ranked as PRG > PSG > UG. In two experiments, the soil available $\mathrm{P}$ and $\mathrm{K}$ contents were increased by post-grafting generation of $C$. bursa-pastoris, which were ranked as: PRG > PSG > UG. The post-grafting generation of $C$. bursa-pastoris enhanced soil sucrase and soil catalase activities in two experiments. The soil urease activity of PSG enhanced compared with UG, but the soil urease activity of PRG decreased. Therefore, grafting could used to increase nutrient content and enhance soil enzyme activity in post generation of $C$. bursa-pastoris for the phytoremediation of $\mathrm{Cd}$.

\section{Introduction}

The grafting is a method of plant propagation that is widely used in horticulture, and has played a significant role on improving the yield and quality of fruit and vegetable [1]. The study of Edelstein and Ben-Hur shows that the boron, zinc, strontium, manganese, copper, titanium, chromium, nickel and cadmium (Cd) contents in grafting watermelon fruit are lower than ungrafted watermelon [2]. The grafting increases the nitrogen, phosphorus and potassium content in cucumber seedlings compared with ungrafted seedlings [3]. Therefore, the grafting could regulate nutrient uptake of plant.

Capsella bursa-pastoris is a winter Cd-accumulator plant with small biomass, and the phytoremediation efficiency of $\mathrm{Cd}$ is low [4]. In this paper, we used rape as stock to graft $C$. bursa-pastoris, and collected seeds and grew in Cd-contaminated soil. The aim of this paper was to study the effects of rape rootstock on phosphorus (P) and potassium (K) uptake and soil enzyme activity of post-grafting generation plants of $C$. bursa-pastoris under Cd stress.

\section{Materials and Methods}

Materials. The $C$. bursa-pastoris seeds were colleted from Ya'an campus farm of the Sichuan Agricultural University $\left(29^{\circ} 59^{\prime} \mathrm{N}, 102^{\circ} 59^{\prime} \mathrm{E}\right)$, China, in December 2012, and directly were sown in soil of plastic pots. When the C. bursa-pastoris seedlings grew at the bolting stage, the grafting was conducted. There were three grafting treatments in the experiment. (1) ungrafted (UG): $C$. bursa-pastoris seedlings remained untreated. (2) Self-rooted grafting by two different sizes of $C$. bursa-pastoris seedlings (SG): The scion and rootstock were from two different growth stages of $C$. bursa-pastoris seedlings. The lower part of $C$. bursa-pastoris seedlings with heights of $3 \mathrm{~cm}(5 \mathrm{~cm}$ for 
the whole plant), were the rootstocks. The scions were the upper parts $(2 \mathrm{~cm})$ of $C$. bursa-pastoris seedlings with $5 \mathrm{~cm}$ of whole plant. (3) Grafting on rootstock of Rape (RG): The lower part of the rape seedlings with heights of $5 \mathrm{~cm}$ were the rootstocks, and the upper parts of the C. bursa-pastoris seedlings, with heights of $2 \mathrm{~cm}$, were the scions. When the grafting was completed, the soil moisture content was maintained at $80 \%$ of field capacity, and all of the seedlings were covered with transparent plastic film and a shade net. After $10 \mathrm{~d}$, the transparent plastic film, the shade net and the plastic binding films were removed, and all the germinating buds of rootstocks were also removed.

High soil $\mathrm{Cd}$ concentration experiment. The high soil $\mathrm{Cd}$ concentration experiment was conducted at the Ya' an campus farm from August to October 2013. The non-contaminated purple soil samples were collected from the Ya'an campus farm. The basic properties of the soil were the same as reference [5]. $3.0 \mathrm{~kg}$ of soil was weighed into each polyethylene pot (15 cm tall, $18 \mathrm{~cm}$ diameter). Cd was added to make a final soil Cd concentration of $50 \mathrm{mg} / \mathrm{kg}$ with a saturated heavy metal solution in the form of $\mathrm{CdCl}_{2} \cdot 2.5 \mathrm{H}_{2} \mathrm{O}$. The soils were mixed immediately and again after 4 weeks, during which time soil moisture was maintained at $80 \%$. The seeds of different rootstock post-grafting $C$. bursa-pastoris plants were sown separately in the farmland of the Ya'an campus farm (non-contaminated area). When the seedlings grew two expanded euphyllas, four uniformly prepared C. bursa-pastoris seedlings from each rootstock treatment were transplanted into each pot. There were three treatments in the experiment: UG, post-grafting generation of SG (PSG), and post-grafting generation of RG (PRG). Each treatment was repeated three times with 10-cm spacing between pots. After C. bursa-pastoris matured ( $35 \mathrm{~d})$, plants were harvested for determining contents of total $\mathrm{P}$ and $\mathrm{K}$ in roots and shoots [6]. The soil samples were collected for determining soil available $\mathrm{P}$ and $\mathrm{K}$ contents [6] and soil enzyme activity [7].

Low soil Cd concentration experiment. The low soil Cd concentration experiment was conducted at the Ya'an campus farm from August to October 2013. The purple soil samples came from the cadmium contaminated soils in the earlier experiment of the Ya'an campus Farm. The basic properties of the soil were the same as reference [8]. The cultivation and management of C. bursa-pastoris seedlings were as described in the high soil $\mathrm{Cd}$ concentration experiment. After C. bursa-pastoris matured ( $35 \mathrm{~d}$ ) plants were harvested. The plants and soils were processed as described in the high soil Cd concentration experiment.

Statistical Analyses. Statistical analyses were performed using SPSS 13.0 statistical software (IBM, Chicago, IL, USA). Data were analyzed by one-way analysis of variance with least significant difference at a $5 \%$ confidence level.

\section{Results and Discussion}

Total $\mathbf{P}$ content in plant. In high soil $\mathrm{Cd}$ concentration experiment, grafting increased the total $\mathrm{P}$ content in post-grafting generation plants of $C$. bursa-pastoris (Table 1). Compared with UG, the total P contents in roots of PSG and PRG increased by $6.91 \%(p>0.05)$ and $15.47 \%(p<0.05)$ respectively, and increased by $11.83 \%(p>0.05)$ and $16.86 \%(p<0.05)$ respectively in shoots of PSG and PRG. In low soil $\mathrm{Cd}$ concentration experiment, grafting also increased the total $\mathrm{P}$ content in post-grafting generation plants of $C$. bursa-pastoris (Table 1). The total P contents in roots of PSG and PRG increased by $3.08 \%(p>0.05)$ and $24.66 \%(p<0.05)$ respectively, and increased by $2.07 \%(p>0.05)$ and $6.90 \%(p>0.05)$ respectively in shoots of PSG and PRG compared with UG. So, grafting could increase $\mathrm{P}$ uptake in $C$. bursa-pastoris, and the rape stock was the best.

Total $\mathrm{K}$ content in plant. The same as total $\mathrm{P}$ content in plants, the total $\mathrm{K}$ content in post-grafting generation of $C$. bursa-pastoris was increased by grafting (Table 2). In high soil Cd concentration experiment, the total $\mathrm{K}$ contents in roots of PSG and PRG increased by $64.29 \%(p<0.05)$ and $72.73 \%$ $(p<0.05)$ respectively compared with $\mathrm{UG}$, and the total $\mathrm{K}$ contents in shoots increased by $28.92 \%$ ( $p$ $<0.05)$ and $33.98 \%(p<0.05)$ respectively compared with UG. In low soil Cd concentration experiment, the total K contents in roots of PSG and PRG increased by $17.99 \%(p<0.05)$ and $27.51 \%$ $(p<0.05)$ respectively compared with UG, and the total K contents in shoots increased by $27.68 \%$ ( $p$ 
$<0.05)$ and $32.92 \%(p<0.05)$ respectively compared with UG. So, grafting could also increase $\mathrm{P}$ uptake in $C$. bursa-pastoris, and the rape stock was the best, which was beneficial to the growth of $C$. bursa-pastoris.

Table 1 Total $\mathrm{P}$ content in C. bursa-pastoris in two experiments

\begin{tabular}{|c|c|c|c|c|}
\hline \multirow{2}{*}{ Treatments } & \multicolumn{2}{|c|}{ High soil Cd concentration experiment } & \multicolumn{2}{c|}{ Low soil Cd concentration experiment } \\
\cline { 2 - 5 } & Roots $(\mathrm{g} / \mathrm{kg})$ & Shoots $(\mathrm{g} / \mathrm{kg})$ & Roots $(\mathrm{g} / \mathrm{kg})$ & Shoots $(\mathrm{g} / \mathrm{kg})$ \\
\hline UG & $3.62 \pm 0.13 \mathrm{~b}$ & $3.38 \pm 0.11 \mathrm{~b}$ & $2.92 \pm 0.10 \mathrm{~b}$ & $2.90 \pm 0.11 \mathrm{a}$ \\
\hline PSG & $3.87 \pm 0.17 \mathrm{ab}$ & $3.78 \pm 0.16 \mathrm{ab}$ & $3.01 \pm 0.08 \mathrm{~b}$ & $2.96 \pm 0.13 \mathrm{a}$ \\
\hline PRG & $4.18 \pm 0.11 \mathrm{a}$ & $3.95 \pm 0.15 \mathrm{a}$ & $3.64 \pm 0.06 \mathrm{a}$ & $3.10 \pm 0.14 \mathrm{a}$ \\
\hline
\end{tabular}

Table 2 Total $\mathrm{K}$ content in C. bursa-pastoris in two experiments

\begin{tabular}{|c|c|c|c|c|}
\hline \multirow{2}{*}{ Treatments } & \multicolumn{2}{|c|}{ High soil Cd concentration experiment } & \multicolumn{2}{c|}{ Low soil Cd concentration experiment } \\
\cline { 2 - 5 } & Roots $(\mathrm{g} / \mathrm{kg})$ & Shoots $(\mathrm{g} / \mathrm{kg})$ & Roots $(\mathrm{g} / \mathrm{kg})$ & Shoots $(\mathrm{g} / \mathrm{kg})$ \\
\hline UG & $3.08 \pm 0.08 \mathrm{~b}$ & $4.15 \pm 0.14 \mathrm{~b}$ & $3.89 \pm 0.10 \mathrm{c}$ & $4.01 \pm 0.13 \mathrm{~b}$ \\
\hline PSG & $5.06 \pm 0.20 \mathrm{a}$ & $5.35 \pm 0.11 \mathrm{a}$ & $4.59 \pm 0.08 \mathrm{~b}$ & $5.12 \pm 0.17 \mathrm{a}$ \\
\hline PRG & $5.32 \pm 0.10 \mathrm{a}$ & $5.56 \pm 0.20 \mathrm{a}$ & $4.96 \pm 0.06 \mathrm{a}$ & $5.33 \pm 0.18 \mathrm{a}$ \\
\hline
\end{tabular}

Soil available $\mathbf{P}$ and $\mathbf{K}$ contents in high soil $\mathbf{C d}$ concentration experiment. In high soil $\mathrm{Cd}$ concentration experiment, the soil available $\mathrm{P}$ content was increased by post-grafting generation of $C$. bursa-pastoris (Table 3). The soil available P content was ranked as: PRG > PSG > UG. Compared with UG, the soil available P contents of PSG and PRG increased by $7.25 \%(p>0.05)$ and $22.54 \%(p$ $<0.05)$ respectively. The soil available $\mathrm{K}$ content was also increased by post-grafting generation of $C$. bursa-pastoris in high soil Cd concentration experiment (Table 3). The soil available $\mathrm{K}$ content was ranked as: PRG > PSG > UG. The soil available K contents of PSG and PRG increased by $2.73 \%$ ( $p>$ $0.05)$ and $4.89 \%(p<0.05)$ respectively compared with UG. Therefore, the post-grafting generation of C. bursa-pastoris enhanced the use efficiency of soil available $\mathrm{P}$ and $\mathrm{K}$, and could promote the growth of $C$. bursa-pastoris which could enhance the phytoremediation ability of $C$. bursa-pastoris.

Soil enzyme activity in high soil $\mathbf{C d}$ concentration experiment. The post-grafting generation of C. bursa-pastoris enhanced soil sucrase and soil catalase activities in high soil $\mathrm{Cd}$ concentration experiment (Table 3). The soil sucrase and soil catalase activities were ranked as: PRG > PSG $>$ UG. Compared with UG, the soil sucrase activities of PSG and PRG enhanced by $65.72 \%(p<0.05)$ and $112.29 \%(p<0.05)$ respectively, and soil catalase activities of that enhanced by $1.44 \%(p>0.05)$ and $8.61 \%(p>0.05)$ respectively. The soil urease activity of PSG enhanced compared with UG, but the soil urease activity of PRG decreased, which might be related to the characteristics of soil enzyme.

Table 3 Soil nutrient content and soil enzyme activity in high soil $\mathrm{Cd}$ concentration experiment

\begin{tabular}{|c|c|c|c|c|c|}
\hline Treatments & $\begin{array}{c}\text { Soil available P } \\
(\mathrm{mg} / \mathrm{kg})\end{array}$ & $\begin{array}{c}\text { Soil available K } \\
(\mathrm{mg} / \mathrm{kg})\end{array}$ & $\begin{array}{c}\text { Soil sucrase } \\
\text { activity }(\mathrm{mg} / \mathrm{g})\end{array}$ & $\begin{array}{c}\text { Soil urease } \\
\text { activity }(\mathrm{mg} / \mathrm{g})\end{array}$ & $\begin{array}{c}\text { Soil catalase } \\
\text { activity }(\mathrm{ml} / \mathrm{g})\end{array}$ \\
\hline UG & $3.86 \pm 0.11 \mathrm{~b}$ & $119.22 \pm 1.10 \mathrm{~b}$ & $0.423 \pm 0.020 \mathrm{c}$ & $0.408 \pm 0.016 \mathrm{~b}$ & $0.209 \pm 0.019 \mathrm{a}$ \\
\hline PSG & $4.14 \pm 0.07 \mathrm{~b}$ & $122.48 \pm 2.15 \mathrm{ab}$ & $0.701 \pm 0.081 \mathrm{~b}$ & $0.490 \pm 0.012 \mathrm{a}$ & $0.212 \pm 0.007 \mathrm{a}$ \\
\hline PRG & $4.73 \pm 0.15 \mathrm{a}$ & $125.05 \pm 1.34 \mathrm{a}$ & $0.898 \pm 0.044 \mathrm{a}$ & $0.256 \pm 0.009 \mathrm{c}$ & $0.227 \pm 0.016 \mathrm{a}$ \\
\hline
\end{tabular}

Soil available $P$ and $K$ contents in low soil $C d$ concentration experiment. The same as in high soil $\mathrm{Cd}$ concentration experiment, the soil available $\mathrm{P}$ content was also increased by post-grafting generation of $C$. bursa-pastoris in low soil $\mathrm{Cd}$ concentration experiment, and the soil available $\mathrm{P}$ content was ranked as: PRG > PSG > UG (Table 4). The soil available K content was also increased by 
post-grafting generation of $C$. bursa-pastoris in low soil Cd concentration experiment, and the soil available P content was ranked as: $\mathrm{PRG}>\mathrm{PSG}>\mathrm{UG}$ (Table 4).

Soil enzyme activity in low soil Cd concentration experiment. The post-grafting generation of $C$. bursa-pastoris enhanced soil sucrase and soil catalase activities in low soil $\mathrm{Cd}$ concentration experiment (Table 4), which was the same as in high soil Cd concentration experiment. However, the PSG enhanced soil urease activity compared with UG, but PRG decreased that (Table 4). Overall, the grafting could enhance the soil enzyme activity, which was benefit for the growth of plant roots.

Table 4 Soil nutrient content and soil enzyme activity in low soil Cd concentration experiment

\begin{tabular}{|c|c|c|c|c|c|}
\hline Treatments & $\begin{array}{c}\text { Soil available P } \\
(\mathrm{mg} / \mathrm{kg})\end{array}$ & $\begin{array}{c}\text { Soil available K } \\
(\mathrm{mg} / \mathrm{kg})\end{array}$ & $\begin{array}{c}\text { Soil sucrase } \\
\text { activity }(\mathrm{mg} / \mathrm{g})\end{array}$ & $\begin{array}{c}\text { Soil urease } \\
\text { activity }(\mathrm{mg} / \mathrm{g})\end{array}$ & $\begin{array}{c}\text { Soil catalase } \\
\text { activity }(\mathrm{ml} / \mathrm{g})\end{array}$ \\
\hline UG & $3.22 \pm 0.10 \mathrm{c}$ & $118.17 \pm 2.59 \mathrm{a}$ & $1.173 \pm 0.146 \mathrm{~b}$ & $0.289 \pm 0.014 \mathrm{a}$ & $0.217 \pm 0.004 \mathrm{a}$ \\
\hline PSG & $3.83 \pm 0.14 \mathrm{~b}$ & $121.32 \pm 2.38 \mathrm{a}$ & $1.420 \pm 0.128 \mathrm{~b}$ & $0.357 \pm 0.065 \mathrm{a}$ & $0.223 \pm 0.017 \mathrm{a}$ \\
\hline PRG & $4.46 \pm 0.06 \mathrm{a}$ & $124.10 \pm 1.27 \mathrm{a}$ & $1.874 \pm 0.126 \mathrm{a}$ & $0.276 \pm 0.006 \mathrm{a}$ & $0.232 \pm 0.012 \mathrm{a}$ \\
\hline
\end{tabular}

\section{Conclusions}

In high and low soil $\mathrm{Cd}$ concentration experiments, the grafting increased $\mathrm{P}$ and $\mathrm{K}$ contents in roots and shoots of post-grafting generation plants of $C$. bursa-pastoris compared with UG under Cd stress. The $\mathrm{P}$ and $\mathrm{K}$ contents in plants were ranked as PRG > PSG > UG. In two experiments, the soil available $\mathrm{P}$ and $\mathrm{K}$ contents were increased by post-grafting generation of $C$. bursa-pastoris, which were ranked as: PRG > PSG > UG. The post-grafting generation of C. bursa-pastoris enhanced soil sucrase and soil catalase activities in two experiments. The soil urease activity of PSG enhanced compared with UG, but the soil urease activity of PRG decreased. Therefore, grafting could used to increase nutrient content and enhance soil enzyme activity in post generation of $C$. bursa-pastoris under Cd stress.

\section{References}

[1] G.L. Chen and C.L. Nie: Vegetable Grafting Cultivation Techniques (Jindun Press, Beijing 2005).

[2] M. Edelstein and M. Ben-Hur, in: Proceedings of the International Symposium on Water Resources Management, edited by J. Wilson, Honolulu, Hawaii, USA (2007).

[3] Y. Sun, W. Huang, X.H. Tian, Y. Wu, Q. Ding and C.T. Zhou: Plant Nutrition and Fertilizer Science Vol. 8 (2002), P. 181.

[4] Y. Liu, L. Lin, Q. Jin and X. Zhu: Environmental Progress \& Sustainable Energy Vol. 34 (2015), p. 663.

[5] L.J. Lin, Q. Jin, Y.J. Liu, B. Ning, M.A. Liao and L. Luo: Environ. Toxicol. Chem. Vol. 33 (2014), P. 2422.

[6] S.D. Bao: Agrochemical Soil Analysis ( $3^{\text {rd }}$ edition, China Agriculture Press, Beijing 2000).

[7] L.K. Zhou: Soil Enzymology (Science Press, Beijing 1987).

[8] L. Lin, Q. Liu, J. Shi, J. Sun, M. Liao and L. Mei: Environ. Toxicol. Chem. Vol. 33 (2014), p. 1950. 